\title{
HUBUNGAN PAPARAN ASAP ROKOK TERHADAP KEJADIAN KETUBAN PECAH DINI DI PUSKESMAS RINGINARUM KABUPATEN KENDAL
}

\author{
Rozikhan ${ }^{1}$, Titik Sapartinah $^{2}$, Ana Sundari ${ }^{3}$ \\ 1,2,3 UPP Kampus Kendal Poltekkes Kemenkes Semarang
}

\begin{abstract}
Premature rupture of membranes is fluid discharge from the birth canal before the onset of labor. One risk factor is a decrease in ascorbic acid which results in abnormal structural growth. Preliminary survey results in Dr. H. Soewondo Kendal in 2013 there were 379 women giving birth with premature rupture of membranes. The purpose of this study was to determine the description of exposure to cigarette smoke in maternal with the occurrence of premature rupture of membranes in Dr. H. Soewondo Kendal. The design of this study is analytical research with cross-sectional study. The population was taken from parturient mother in RSUD Dr. H. Soewondo Kendal in May-June 2014 as many as 78 birth mothers consisting of 39 mothers with Premature rupture of membranes and 39 with no Premature rupture of membranes delivery. The sampling technique uses accidental sampling. Data collection using checklists and questionnaires. The results were obtained by 29 pregnant women (74.4\%) with Premature rupture of membranes exposed to cigarette smoke and 10 people (29.4\%) exposed to Premature rupture of membranes. While 15 respondents (34.1\%) were not exposed to cigarette smoke and 24 (70.6\%) were not exposed to cigarette smoke. Bivariate analysis results showed a $p$-value of $0.003<\alpha-0.05$. The conclusion is that there is a significant relationship between the incidence of Premature rupture of membranes in pregnant women with cigarette smoke exposure. Advice for midwives is to give advice to every pregnant woman to avoid cigarette smoke and provide quick and appropriate assistance to mothers who give birth with premature rupture of membranes so that it will reduce the danger of infection.
\end{abstract}

Keywords: Premature rupture of membranes, exposure, cigarette smoke 


\section{PENDAHULUAN}

Angka kematian lbu (AKI) merupakan salah satu indikator untuk mengetahui derajat kesehatan perempuan. Urutan penyebab kematian Ibu melahirkan adalah perdarahan (28\%), eklampsi (24\%), infeksi (11\%). (Depkes 2007).

Ketuban pecah dini dalam persalinan adalah keluarnya cairan dari jalan lahir atau vagina sebelum proses persalinan.(Marmi,2011;h,103)

Ketuban pecah dini (KPD) disebabkan karena berkurangnya kekuatan sesuatu membran atau meningkatnya tekanan intrauterine atau karena oleh kedua faktor tersebut. (Prawiharjo,2010;h.218).

Faktor risiko untuk terjadinya ketuban pecah dini (KPD) yaitu berkurangnya asam askorbik sebagai komponen kolagen, kekurangan tembaga dan asam askorbik yang berakibat pertumbuhan struktur abnormal karena antara lain merokok.

Hasil study pendahuluan di RSUD dr. H. Soewondo kabupaten Kendal jumlah ibu bersalin periode bulan Januari sampai Desember 2013 sebanyak 3350 orang. Dari data tersebut terdapat ibu bersalin dengan preeklampsia berjumlah 538 orang $(16,0 \%)$ orang, ibu bersalin dengan ketuban pecah dini berjumlah 379 (11,3\%) orang, ibu bersalin dengan partus prematurus sebanyak 262 (7,8\%), ibu bersalin sungsang berjumlah $207(6,1 \%)$, ibu bersalin dengan partus tak maju berjumlah 148 (4,4\%) orang, dan 1816 $(54,4 \%)$ orang lainnya dengan masalah lain.

Dari faktor resiko dan data tersebut penulis tertarik untuk melakukan penelitian tentang "gambaran paparan asap rokok terhadap kejadian ketuban pecah dini di RSUD Dr. H. Soewondo kabupaten Kendal".

Tujan umum adalah untukntuk mengetahui gambaran paparan asap rokok terhadap kejadian ketuban pecah dini di RSUD Dr. H. Soewondo kabupaten Kendal

\section{METODOLOGI PENELITIAN}

Penelitian ini menggunakan crossectional study yaitu suatu metode penelitian yang bertujuan untuk melihat apakah asap rokok (sebagai variable bebas) dapat mempengaruhi kejadian KPD pada ibu bersalin (sebagai variable terikat). (Hidayat, 2007; h. 86)

Populasi adalah keseluruhan subyek penelitian. Populasinya adalah semua ibu bersalin dengan ketuban pecah dini di RSUD Dr. H Soewondo Kabupaten Kendal pada bulan Mei- Juni 2014. Sampel dalam penelitian ini adalah sebagian ibu bersalin yang mengalami ketuban pecah dini di RSUD Dr. H Soewondo Kabupaten Kendal bulan Mei - Juni 2014. Teknik pengambilan sampel pada penelitian ini menggunakan teknik sampling Aksidental (Accidental Sampling) yaitu sampling yang dilakukan dengan mengambil kasus atau responden yang kebetulan ada atau tersedia di suatu tempat sesuai dengan 
konteks

penelitian.

(Notoatmojo,2010;h.125)

Alat yang digunakan dalam penelitian ini adalah kuesioner dan cheklist. Kuesioner merupakan alat ukur berupa angket atau pertanyaanpertanyaan. Pengambilan data dengan menggunakan data primer dan sekunder. Data primer yang digunakan dalam penelitian ini diambil dari jawaban para responden untuk mengetahui paparan asap rokok pada pasien ibu bersalin dengan ketuban pecah dini. Data sekunder dalam penelitian ini didapat dari buku register diruang VK RSUD Dr.H.Soewondo Kendal yang berisi no register dan diagnosa.

Pengolahan data melalui langkah Editing (Pemeriksaan Data), Coding (Pemberian Kode) dan Data Entry (Memasukkan Data). (Hidayat, 2007; h. 121-122)

Analisa data menggunakan analisis univariate bertujuan untuk menjelaskan atau mendeskripsikan karakteristik dari setiap variabel penelitian. Bentuk analisis univariate tergantung dari jenis datanya. (Notoatmodjo, 2010; h. 182)

Langkah-langkah menghitung teknik persentase yaitu :

(a) Menghitung perolehan jumlah jawaban.

(b) Menghitung persentase yang dicapai dengan menggunakan rumus :

$$
\mathrm{X}=\frac{n}{N} \times 100 \%
$$

Keterangan :
$\mathrm{X}$ : Jumlah persentase

$\mathrm{n}$ : Nilai yang diperoleh ( bersalin dengan KPD)

$\mathrm{N}$ : Jumlah seluruh ibu bersalin

Etika Penelitian yang dilakukan menggunakan lembar persetujuan menjadi responden (Inform consent), tanpa nama (Anonomity) dan menjaga kerahasiaan (Confidentiality).

\section{HASIL PENELITIAN DAN BAHASAN}

Tabel 4.1 Distribusi Frekuensi lbu Bersalin yang Terpapar Asap Rokok di RSUD Dr. H. Soewondo Kendal Bulan Mei- Juni 2014

\begin{tabular}{|c|c|c|}
\hline $\begin{array}{c}\text { Riwayat } \\
\text { Paparan } \\
\text { Asap } \\
\text { Rokok }\end{array}$ & Frekuensi & $\begin{array}{r}\text { Persentase } \\
(\%)\end{array}$ \\
\hline Terpapar & 44 & 56,4 \\
\hline $\begin{array}{l}\text { Tidak } \\
\text { Terpapar }\end{array}$ & 34 & 43,6 \\
\hline Jumlah & 78 & 100 \\
\hline
\end{tabular}

Berdasarkan Tabel 4.1 diketahui bahwa ibu bersalin yang terpapar asap rokok sebanyak $44(56,4 \%)$ dan yang tidak terpapar asap rokok sebanyak 34 (43,6\%) ibu bersalin

Tabel 4.2 Gambaran riwayat paparan asap rokok pada ibu bersalin dengan KPD di RSUD Dr. H. Soewondo Kendal Bulan MeiJuni 2014

\begin{tabular}{|c|c|c|c|c|}
\hline \multirow{2}{*}{$\begin{array}{l}\text { Riwayat } \\
\text { Paparan } \\
\text { Asap } \\
\text { Rokok }\end{array}$} & \multicolumn{2}{|c|}{$\begin{array}{c}\text { Bersalin } \\
\text { dengan KPD }\end{array}$} & \multirow[t]{2}{*}{$\begin{array}{r}\text { Total } \\
(\%) \\
\end{array}$} & \multirow[b]{2}{*}{ Nilai $p$} \\
\hline & $\begin{array}{l}\mathrm{Ya} \\
(\%)\end{array}$ & $\begin{array}{c}\text { Tidak } \\
(\%)\end{array}$ & & \\
\hline $\mathrm{Ya}$ & $\begin{array}{l}29 \\
(65,9)\end{array}$ & $\begin{array}{c}15 \\
(34,1)\end{array}$ & $\begin{array}{r}44 \\
(100)\end{array}$ & \\
\hline Tidak & $\begin{array}{l}10 \\
(29,4)\end{array}$ & $\begin{array}{c}24 \\
(70,6)\end{array}$ & 34(100 & 0,003 \\
\hline Total & $\begin{array}{c}39 \\
(50)\end{array}$ & $\begin{array}{c}39 \\
(50)\end{array}$ & $\begin{array}{r}78 \\
(100)\end{array}$ & \\
\hline
\end{tabular}


Berdasarkan Tabel 4.2 diketahui bahwa ibu bersalin dengan ketuban pecah dini yang terpapar asap rokok berjumlah 29 $(65,9 \%)$ orang, dan ibu bersalin dengan ketuban pecah dini yang tidak terpapar asap rokok berjumlah 10 (29,4\%) orang.

Sedangkan ibu bersalin yang tidak mengalami ketuban pecah dini dan yang tidak terpapar asap rokok berjumlah 15 $(34,1 \%)$ orang dan ibu bersalin tidak dengan ketuban pecah dini yang tidak terpapar asap rokok berjumlah 24 (70,6\%) orang. Hasil analisis diperoleh nilai-p 0,003 lebih kecil dari nilai $\alpha-0,05$ dengan kata lain terdapat perbedaan antara ibu melahirkan dengan KPD yang terpapar asap rokok dengan yang tidak terpapar asap rokok.

Dari hasil penelitian tentang gambaran paparan asap rokok terhadap kejadian ketuban pecah dini di RSUD Dr. H Soewondo Kendal. Hasil penelitian menunjukkan bahwa ibu yang terpapar asap rokok dan mengalami KPD sebanyak 29 orang (65,9\%). Sebagian besar menyatakan bahwa ada anggota keluarga yang merokok di dalam rumah, dan sebagian kecil ada rekan kerja yang merokok di dalam ruangan.

Berdasarkan analisa bahwa paparan asap rokok dapat mempengaruhi terjadinya persalinan KPD di RSUD Dr.H. Soewondo Kendal. Hal ini menunjukkan bahwa paparan asap rokok dapat meningkatkan risiko terjadinya ketuban pecah dini pada persalinan.
Asap rokok merupakan polutan bagi manusia maupun lingkungan sekitarnya. Asap rokok membuat lebih berbahaya terhadap perokok pasif daripada perokok aktif. Asap rokok yang dihembuskan oleh perokok aktif dan terhirup oleh perokok pasif, sebanyak empat kali lebih banyak mengandung tar dan nikotin, 5 kali lebih banyak mengandung karbon monoksida yaitu merupakan radikal bebas yang dapat menimbulkan kerusakan tubuh. (Anonymous,2013)

Dampak negatif rokok dan asapnya terhadap ibu hamil diantaranya kelahiran prematur, ketuban pecah sebelum waktunya, ancaman lepasnya plasenta sebelum lahir, plasenta previa, ketuban pecah dini, sedangkan dampak terhadap janin adalah berat badan janin lebuh rendah dari normal,kematian janin di dalam rahim, meningkat resiko kematian janin mendadak (sudden infant death syndrom/ SIDS).( Valeria, 2009)

Ketuban pecah dini disebabkan karena berkurangnya kekuatan membran atau meningkatnya tekanan intrauterin atau oleh kedua faktor tersebut. (Prawiroharjo,2010;h218) Berkurangnya kekuatan membran diantaranya disebabkan oleh rokok. Rokok mengandung nikotin yang dapat mempengaruhi kekuatan membran ketuban. (A resource for professionals and community organizations, 2012)

Hasil penelitian ini sesuai dengan teori yang menyebutkan bahwa faktor risiko untuk terjadinya ketuban pecah dini yaitu 
berkurangnya asam askorbik sebagai komponen kolagen. Sementara itu serum tembaga dan asam askorbat yang penting untuk sintesis kolagen dan pemeliharaan. (Davids, 2011)

Kekurangan tembaga dan asam askorbik yang berakibat pertumbuhan struktur abnormal karena antara lain merokok. (Prawirohajo,2009;h.678)

Kekurangan tembaga dan asam askorbik yang berakibat pertumbuhan struktur abnormal karena antara lain merokok. (Prawirohajo,2009;h.678)

\section{KESIMPULAN}

Dari hasil penelitian tentang hubungan paparan asap rokok terhadap kejadian ketuban pecah dini di RSUD Dr. H Soewondo Kendal menunjukkan bahwa ibu bersalin dengan KPD yang terpapar asap rokok sebanyak (65\%) sedangkan ibu bersalin yang KPD dan tidak terpapar rokok sebanyak (29\%), hal ini menunjukkan terdapat hubungan yang signifikan antara ibu melahirkan yang menalami KPD dengan paparan asap rokok ( $p$-value $0,003<\alpha-0,05$ ).

Disarankan bagi masyarakat agar mampu mengetahui dampak dari rokok dan menghindari asap rokok khususnya bagi ibu hamil. Perlunya meningkatan pengetahuan ibu dengan memberikan penyuluhan kesehatan tentang bahaya asap rokok bagi ibu hamil

\section{DAFTAR PUSTAKA}

1. A resource for professionals and community organizations. Enviromental Tobacco smoke the risk to unborn babies, pregnant women and children. Saskatchewan Prevention institute. 2012. p.1-20 [diakses tanggal 14 januari 2014]. didapat dari http://www.skprevention.ca

2. Amasha. $\mathrm{H}$, Jaraeh. M. Effect of active and passive smoking during pregnancy on this outcomes. Health Science Journal, Volume 6, Issue 2 (April- june 2012). P.335-346. [diakses tanggal 14 januari] didapat dari http://ejournal.undip.ac.id

3. Anonymous. Kebutuhan gizi ibu hamil. 18 April 2013 [diakses tanggal 6 Februari 2014]. Didapat dari http://dinkes.sumbarprov.go.id

4. Anonymous. Perokok pasif. 11 August 2013 [diakses 16 januari 2014] didapat dari http://kesehatan.kompasiana.com

5. Arikunto, Suharsimi. Prosedur Penelitian Suatu Pendekatan Praktik. Jakarta :Rineka Cipta; 2006

6. BKKBN (2012). Angka Kematian Ibu. 23 september 2013. [Diakses 7 januari 2014] di dapat dari http://www.bkkbn.go.id

7. Chandra, Budiman. Metodologi penelitian kesehatan. Jakarta: EGC; 2008.

8. Davids. Tobacco Use abefore, During, or After Pregnancy, A Pregnancy Risk Assesment Monitoring System Quarterly Report V.2 No.1.2011.p.1-6 [diakses tanggal 10 Januari 2014] didapat dari http://ejournal.undip.ac.id

9. Depkes RI (2012). Profil Kesehatan Profinsi Jawa Tengahn 2012.[diakses 14 januari 2014] didapat dari http://www.dinkesjatengprov.go.id

10. Depkes RI (2007). Penyebab Kematian Ibu. 7 februari 2012.[diakses tanggal 6 januari 2014] didapat dari http://www.infodokterku.com

11. D, Nita Norma, Mustika Dwi S. Asuhan Kebidanan Patologi. Yogyakarta: Nuha Medika;2013.

12. Elektrina. Angka Kematian Ibu. 2011;h.1-2 [diakses tanggal 7 Januari 2014] didapat dari http://repository.usu.ac.id

13. Elizabeth, Aula. Stop Merokok. Jogjakarta: Gerai IImu; 2010. 
14. Hidayat, Alimul Aziz. Metode Penelitian Kebidanan Teknik Analisis Data.Jakarta: Salemba Medika; 2007.

15. Hofmeyr, G. J, et all. A Cochrane Pocketbook Pregnancy and Childbirth. John Wiley \& Son Ltd. Medicine. Vol 6. Issue 2. 2008. p.55-56 [diakses tanggal 10 Januari].didapat dari http://ejournal.undip.ac.id

16. Tobacco Control Support Center.Ikatan Ahli Kesehatan Masyarakat Indonesia. Perlindungan terhadap paparan Asap Rokok Orang lain: mengapa perlu? Seri 1. h.3. 2008. [diakses tanggal 3 maret 2014] didapat dari.

17. Marmi, A. Retno Murti Suryaningsih, Ery Fatmawati. Asuhan Kebidanan Patologi. Yogyakarta: Pustaka Pelajar ;2011.

18. Manuaba, dkk. Pengantar kuliah obstetri. Jakarta: Penerbit Buku Kedokteran EGC; 2007.

19. Manuaba, dkk. Pengantar kuliah obstetri. Jakarta: Penerbit Buku Kedokteran EGC; 2008.

20. Manuaba,Ida Ayu Chandra. IImu Kebidan, Penyakit kandungan, dan KB untuk pendidikam bidan. Jakrta: EGC; 2010

21. Mastur, Aya. Bisops Score. 23 Oktober 2011 [diakses 18 Februari 2014] didapat dari http://www.scribd.com

22. Mochtar, Rustam. Sinopsis Obstetri: Obstetri Fisiologi, obstetri patologi, Ed.3, jilid 1.Jakarta: EGC; 2011.

23. Muntoha. Hubungan antara riwayat paparan asap rokok dengan kejadian ketuban pecah dini pada ibu hamil di RSUD Dr. H. Soewondo Kendal. Jurnal kesehatan lingkungan indonesia Vol.12 No.1. h.88-92/ April 2013 [ diakses tanggal 16 Januari 2014] didapat dari http://ejournal.undip.ac.id

24. Mustafa. 2011. Dilema of Women's Passive Smoking. Annals of Thoracic of medicine. Vol 6. Issue 2. Page 55-56. [diakses tanggal 18 Januari 2014] didapat dari http://connection.ebscohost.com

25. Nasir, Abdul, Abdul Muhith, M. E. Ideputri. Buku ajar metodologi penelitian kesehatan. Yogyakarta: Nuha Medika; 2011.

26. Notoatmojo. Metodologi Penelitian Kesehatan. Jakarta: Rineka Medika; .2010.
27. Oktavianis. Efek Pemberian Asap Rokok terhadap Kehamilan Tikus Putih (Rattus norvegicus). 2011 [diakses tanggal 20 Januari 2014] didapat dari http://pasca.unand.ac.id

28. Prawiroharjo, Sarwono. IImu Kebidanan. Jakarta: penerbit Yayasan Bina Pustaka; 2009.

29. Prawiroharjo, Sarwonno. Pelayanan Kesehatan Maternal dan Neonatal. Jakarta: Penerbit Yayasan Bina Pustaka; 2010.

30. Sativa, Rahma Lillahi. Paparan Merokok Saat Hamil Membuat Perilaku Bayi Risky Terkena Gangguan. 31 Maret 2013 [dikases tanggal 1 maret 2013] didapat dari http://www.detikhealth.com

31. Simpson, David dan John Crofton. Tembakau ancaman global . jakarta: PT. Elex Media Komputerindo; 2009. 